\title{
THE RULE AGAINST MULTIPLE FICTIONS
}

\author{
BRUCE ZIFF*
}

\begin{abstract}
The author explores aspects of the constructive mens rea found in the Criminal Code, primarily as these relate to accomplices to murder. By examining both basic principles of criminal liability in Canada and the rationale of constructive mens rea, the author seeks to expose the harshness of the current rules, which, when applied to accomplices, tend to compound constructive mens rea provisions. In result, the author proposes that the law adopt a 'rule against multiple fictions', designed to preclude that compounding.
\end{abstract}

\section{INTRODUCTION}

This article will consider the previously unknown 'rule against multiple fictions', which may be stated by means of this simple mathematical formula: one legal fiction + another legal fiction = science fiction. In essence, this rule is designed to prevent the compounding of constructive criminal liability. For example, it would preclude combining the constructive mens rea attributed to a party to an offence under s. 21(2) of the Criminal Code with the constructive mens rea provisions for homicide under s. 213 to create a convoluted definition of murder. To emphasize the point, this combination can result in a conviction for murder of a party who intended to assist (and did so) in a minor way in a robbery, in which a death was caused by his partner in crime. Under the proposed rule this would create a 'science fiction', which of course is mere hyperbole, used to highlight the unfair consequences which can result from multiplying the fictions. Presently, there is no principle preventing this type of combination and indeed there are several well-known Canadian cases in which the sections referred to above have been used to found liability for murder.' It will be maintained that a rule against multiple fictions should be recognized by the criminal law as a limit on such extensions.

There are two premises which inform the present discussion. The first, which is even less unique than it is profound, is that true or serious crimes require proof of a subjective mental element. In its pure form this element normally involves an intention to perform the prohibited act, or recklessness subjectively defined, and knowledge (or recklessness or wilful blindness) as to the material facts in the definition of the offence. Of course, this is general doctrine and although honoured more by breach than observance in relation to quasi-crimes, it has been confirmed by high authority that these principles govern within the traditional ambit of the criminal law. ${ }^{2}$

The law did not always regard the existence of a guilty mind as essential to a finding of culpability, ${ }^{3}$ so it is useful to reflect briefly as to why the

- Bruce Ziff, Associate Professor of Law, University of Alberta.

1. See e.g., R. v. Trinneer [1970] S.C.R. 638, which is discussed extensively, along with other relevant authorities, in Part III, infra.

2. See R. v. City of Sault Ste. Marie [1978] 2 S.C.R. 1299.

3. "Up to the twelfth century the conception of mens rea in anything like its modern sense was non-existent": R.B. Sayre, "Mens Rea" (1931-32) 43 Harv. L. Rev. 974 at 981 . But from the earliest times the existence of a malevolent intent affected punishment: $i d$. at 981-82. See also G. Parker, "The Evolution of Criminal Responsibility" (1971) 9 Alta. L. Rev. 47. Cf. J.W.C. Turner, "The Mental Element in Crimes at Common Law" in The Modern Approach to Criminal Law 1985 (1945); A. Levitt, "The Origin of the Doctrine of Mens rea" (1922-23) 17 III. L. Rev. 117. 
current regime has embraced the mens rea concept. A basic response is that the criminal law should be reserved for those who are at fault. To treat as blameworthy those persons who have caused an undesirable consequence to occur, even if that person acted unintentionally and without negligence, seems "inappropriate, immoral and unfair", ${ }^{4}$ and potentially oppressive. A penal system predicated (at least in part) on deterrence should not punish the accidental, or blameless wrongdoer.

Requiring fault beyond a causal connection between the actions of the accused and the anti-social consequences which are produced, begs the more vexing question as to whether this component can be satisfied solely by showing the accused possessed a subjective intention to cause harm, or whether objective negligence will suffice. It is trite to observe that this is an issue which has engendered considerable debate. According to an extreme view, negligence has no place in the definition of criminal conduct. The criminal law, being a crude device, a "blunderbuss", 5 as Stuart graphically describes it, should be reserved for the most deviant of malefactors; this encompasses the conscious risk takers, or at least those who advert to the risks which they are creating and unjustifiably press on nonetheless. Left alone, or rather subject only to civil liability, are those who produce a prohibited result through stupidity, thoughtlessness or mental subnormality. By avoiding the use of the criminal law to punish negligence, the potency of the stigma of criminality is not diluted ${ }^{6}$ and respect for the criminal justice system as a rational process to prevent anti-social behaviour is buttressed. Eliminating an inquiry into negligence also removes from the responsibility of the trier of fact the difficult problem of ascertaining what ought to have occurred, what the accused ought to have foreseen and other similar questions which are difficult to resolve.?

The responding view proceeds on the assumption that negligence is equally founded on blameworthiness: a man who is careless may neither intend nor foresee, to any degree whatsoever, the serious harm which he causes, yet he can be blamed for this result because of his negligence. ${ }^{8}$ This is an area well mapped in the law of torts. One of the purported reasons for retaining personal liability for personal injuries (as opposed to creating a no-fault accident compensation scheme) is that tort law serves as a general deterrent to careless (and sometimes even non-careless) behaviour.' This

4. D.R. Stuart, Canadian Criminal Law: A Treatise (1982) 115.

5. Id.

6. See J. Hall, "Negligent Behaviour Should Be Excluded From Penal Liability" 11 (1963) 63 Colum. L. Rev. 632; Comment, "Is Negligence a Defensible Basis for Penal Liability?" (1967) 16 Buffalo L. Rev. 749; see also Leary v. The Queen [1978] 2 S.C.R. 29 at 34 (per Dickson J. (as he then was) dissenting).

7. J. Hall, supra n. 6 at $642-43$.

8. See H.L.A. Hart, "Negligence, Mens Rea and Criminal Responsibility" in Punishment and Responsibility (1968) 136 at 152-57. See also A.W. Mewett, "The Shifting Basis of Criminal Law" (1963) 9 McGill L.J. 124; M.J. Julian, "A Determinist's Perspective of Criminal Responsibility" (1970) 8 Alta. L. Rev. 376; G.O.W. Meuller, "On Common Law Mens Rea" (1957-58) 42 Minn. L. Rev. 1043 at 1064; R. Moreland, A Rationale of Criminal Negligence (1944) 40; O.W. Holmes, The Common Law (1881) 49-51. For an interesting analysis in a Canadian setting, see D. Galloway, "Why the Criminal Law is Irrational" (1985) 35 U. of T. L. J. 25. See also A. Levitt, "Extent and Function of the Doctrine of Mens Rea" (1922-23) 17 III. L. Rev. 578.

9. See Royal Commission on Civil Liability for Personal Injury 363 (Cmnd. 7054: 1975). 
exposes the fallacy of assuming that the deterrent function of criminal sanctions can only be served by reserving punishment for those who intentionally flout the law. Moreover, the public may well regard someone who is oblivious to the safety of others to be a criminal, albeit his actions are completely inadvertent.

The present law recognizes a place for negligence, particularly in relation to regulatory offences, and examples of criminal liability based on breaches of a civil standard of care are peppered throughout the Code. ${ }^{10}$ The current focus is presently on the degree to which negligence should be recognized as a form of fault." A subsidiary issue is the extent to which particular characteristics of an accused should be taken into account in determining whether an individual was negligent. ${ }^{12}$ Yet since criminality based on a form of mens rea less than the paragon constitutes a departure from principle, it should follow that departures should be carefully defined to conform to the reasons supporting the departure.

The second premise is less controversial and by no means novel, although some relatively new and helpful terms will be employed. It is that the law should strive for rationality in its formulation and this entails the need to define precisely criminal offences. Glanville Williams has called this "fair labelling", 13 improving slightly on Ashworth's phrase "representative labelling". ${ }^{14}$ What this means is that "the legal designation of an offence should fairly represent the nature of the offender's criminality". ${ }^{15}$ Such a principle would be applicable not merely to the cognomen identifying the offence, but equally to its constituent parts. Therefore, it might be objectionable to treat as robbery an assault perpetrated with an intent to steal, as the Criminal Code now provides. ${ }^{16}$ Robbery suggests a crime of property involving a wrongful taking or deprivation which is committed in a forceful or threatening manner. Where there is merely an assault with an intent to steal, the appropriate description would be either

10. See e.g., Criminal Code, R.S.C. 1970, c. C-34, ss. 253, 77, 78, 267 and 200. See also D.R. Stuart, Annotation: R. v. Tutton (1985) 44 C.R. (3d) 193. See generally R. v. Hill (1986) 25 C.C.C. (3d) 322 (S.C.C.).

11. See Stuart, supra n. 4 at 184-87, and the authorities and commentaries cited therein.

12. See W.A. Seavey, "Negligence Subjective or Objective?" (1927-28) 41 Harv. L. Rev. 1. See e.g., R. v. LeClerc (1984) 27 M.V.R. 72 (Que. C.A.).

13. G. Williams "Convictions and Fair Labelling" [1983] C.L.J. 85.

14. A.J. Ashworth, "the elasticity of mens rea" in Crime, Proof \& Punishment (1981) 45 at 53-6. "'Representative' does not immediately convey the intended meaning because it is a word frequently used in relation to representative courts, representative actions, representative government, and so on, where the few are taken to stand for the many. For this reason it seems to me that "fair labelling" would serve better.": G. Williams, supra $n .13$ at 85.

15. Ashworth, supra n. 14 at 53. See also L.L. Fuller, Anatomy of the Law (1968) at 26: The ills and disorders of a legal system - at least those that come about despite reasonable good intentions - can all be attributed to the fact that those concerned with the law are not clear as to what it is they are trying to do. If the law as a whole could be assigned some understandable general purpose, and if each separate law carried its own distinct purpose, plainly stated, then all these difficulties would disappear. Judges would then know how to interpret the law, the agencies of enforcement would know what their task was, and the general public would understand what was going on and would be able to pass an intelligent judgment on it. Finally, if the legislator were compelled to clarify his aims and to set them forth plainly, he would not be able to visit his obfuscations on the work of others. Everyone's task would 'then receive new meaning and direction'.

16. Criminal Code, R.S.C. 1970, c. C-34, s. 302(c). 
common assault (the purpose being irrelevant) or perhaps attempted robbery. The principle would be violated by permitting extended or elastic definitions of mens rea to suffice for a given of fence, even if the mens rea remained subjective. To illustrate, the law might allow a generalized form of intention for arson or related offences, such as the intention to cause damage to chattels. Ashworth would regard this as unrepresentative, for it would treat as an arsonist one who might have intended to cause damage of a very different kind. ${ }^{17}$

Apart from the "sense of injustice" ${ }^{18}$ which might be fostered, the failure to identify and distinguish properly among different kinds and degrees of wrong-doing can produce harmful results. The stigma of committing a particular crime may weigh too heavily (or lightly) on an individual. Among other results, this can have a serious and direct impact where there is a second conviction and the previous record is examined in sentencing.

Improper labelling can frustrate law enforcement: consider the developments in the area of driving offences. Under the current law, the offences of criminal negligence causing death (s. 203) and manslaughter by criminal negligence (ss. 205(5) and 217) are virtually identical, ${ }^{19}$ and at first glance that duplication appears baffling. Section 203 was presumably added because in cases involving death occurring as a result of traffic accidents, juries were thought too reluctant to convict for manslaughter, or motormanslaughter as it is sometimes called. By creating a new offence of causing death by criminal negligence, it was thought that this reluctance to convict would be lessened. ${ }^{20}$ The amendment was a mere legislative sleight of hand; the components of the offence were not meant to be altered and the penalty remained the same. Still, the expectation appears to have been that this cosmetic change would overcome an irrational impediment to the proper application of the Code.

Fair labelling promotes the law's educative and preventive function, a point not stressed by Williams or Ashworth. That criminal law prohibitions should be clear, accessible and intelligible is an unassailable proposition, and the Law Reform Commission of Canada, in particular, has been extremely sensitive to these goals for at least a decade. ${ }^{21}$ An incident of this is that the legal definitions of crime should accord, as closely as possible, with commonly held perceptions of what these crimes involve $e^{22}$ and of equal importance, dissimilar acts should not be grouped under the rubric of one offence.

17. Supra n. 14 at 53-4.

18. Williams, supra n. 13 at 85 .

19. The conclusion that the offences are exactly the same is resisted because under s. 203, the death of a "person" must result, whereas in manslaughter the victim must be a "human being". Though this distinction may be specious, it was nevertheless drawn by Millward Co. Ct. J. in R. v. Marsh (1979) 2 C.C.C. (3d) 1 (B.C. Co. Ct.), where it was held that a fetus may (depending on its development) be a "person" even though it could not satisfy the definition of a "human being" in s. 206 of the Code, which requires that the human being born that it is, must "completely [proceed] in a living state, from the body of its mother . . ".

20. See S.W. Mewett and M.M. Manning, Criminal Law (2nd ed. 1985) 193; but cf. R. v. Williams (1981) 63 C.C.C. (2d) 141 at 148 (Man. C.A.).

21. See generally Law Reform Commission of Canada, Our Criminal Law (1976).

22. See also E.R. Meehan, The Law of Criminal Attempt (1984) 15; but cf. id. at 49-50. 
Although this terminology may be new, the ideas represented are not. It is the unfair labelling of culpability which occurred in $R$. v. Kundeus ${ }^{23}$ that has made that decision so infamous. Kundeus was caught trafficking in L.S.D. However, it was doubtful whether he had intended to sell anything other than mescaline, this latter drug being a different legal category than L.S.D., to which lesser penalties applied. One would have expected that the appropriate conviction would have been for attempted trafficking in mescaline, but instead Kundeus was convicted of trafficking in L.S.D.; in essence, it was the improper labelling which occurred that attracted a raft of criticism $^{24}$ and formed the central aspect of Laskin J's compelling dissent.

In sum, chosen as the crucibles to assess the multiple fictions phenomenon are two basic notions. By examining dramatic exceptions to subjectivism and improper labelling, it will be argued that party liability in the Canadian homicide regime suffers from deficiencies in both substance and form.

\section{CONSTRUCTIVE MENS REA: IDENTIFYING THE FICTIONS}

From Ashworth's work a further point may be gleaned. He deprecated the use of constructive liability in the criminal law, ${ }^{25}$ but more significantly, he recognized that identifying constructive and non-constructive elements in criminal sanctions can at times be troublesome. ${ }^{26}$ Therefore, it is useful to understand what is (and what is not) meant by the phrase constructive liability before discussing the ways in which constructive elements of murder and party liability differ from intentional forms of culpability.

A constructive definition extends the natural or ordinary meaning of a word, conveying to it a meaning which is often uncommon, perhaps even unrealistic. Sometimes this is referred to as a legal fiction, ${ }^{27}$ and generally it is done so that both the natural and extended meanings can be treated in the eyes of law as essentially the same. The technique of using constructive definitions is found throughout the law. ${ }^{28}$ Yet many of these, dictated by divergent notions of logic and policy, may share the same adjective but otherwise have little in common. Each can be set on a continuum designed

23. [1976]2 S.C.R. 272.

24. G. Parker, "Mistake of Fact Versus Transferred Intent" (1976) 32 C.R.N.S. 150; G. Parker, An Introduction to Criminal Law (2nd ed. 1983) 236; A.W. Mewett and M.M. Manning, supra n. 20, at 175, D.R. Stuart, supra n. 4, at 254-60; E. Oscapella, Note (1976) 8 Ottawa L. Rev. 91; J. Weiler, "Regina v. Kundeus: The Saga of Two Ships Passing in the Night" (1976) 14 Osgoode Hall L.J. 457; A.J. Ashworth, supra n. 14 at 60. See also Law Reform Commission of Canada, Criminal Law: The General Part 73 (Working Paper 29, 1982); G. Williams, Textbook of Criminal Law (1978) 81, n. 3; D.A. Schmeiser, Canadian Criminal Law: Cases and Comments (4th ed. 1981) 257.

25. Supra $\mathrm{n} .14$ at 52.

26. "The difficulty is that the notion of constructive liability only makes sense in relation to agreed categories of offence. We cannot intelligibly use the notion as a critical tool unless there are some reasonably clear dividing lines in moral or ordinary discourse among types or grades of crime": id. at 53.

27. See L.L. Fuller, Legal Fictions (1967); J. Smith, "Surviving Fictions" (1918) 27 Yale L.J. 317; Gray, Nature and Sources of the Law (2nd ed. 1921); Mitchell, The Fictions of the Law (1893).

28. See Black's Law Dictionary (4th ed. 1968) 377-78, where a host of 'constructive' terms are defined. 
to chart the extent to which the fictional definition resembles what may be called the 'base concept'. For example, at the end notionally marked 'close resemblance' can be placed the family law concept of constructive desertion. The distinction between the base concept of desertion and constructive desertion turns on whether the so-called guilty spouse left the home (desertion) or forced the other out by expulsive conduct (constructive desertion). ${ }^{29}$ It would not be sensible to treat these two scenarios differently. The key is that the spouses are no longer together and the law can attribute this to the matrimonial fault of one party; nothing could be less important than who actually left the home. There, the two terms represent different sides of the same coin.

Constructive mens rea forms tend to fall very near the other end of the continuum. These do not merely describe the second side of one coin; rather, the currency of negligence is inflated to that of intentional wrongdoing. ${ }^{30}$ Despite obvious differences, the base concept and its constructive counterpart are occasionally grouped together in pivotal places both in the murder regime and in relation to criminal complicity. These will now be considered.

\section{A. MURDER}

The constructive component of the offence of murder refers here exclusively to the mental element. ${ }^{31}$ An intention to kill is considered as the base not because murder has historically been defined in that way; that certainly has not been so. Initially murder described a killing in secret and the modern distinction between murder and manslaughter did not begin to crystallize until the 17 th century. ${ }^{32}$ Moreover, the legal definition of 'malice aforethought', which for centuries has served as the catch-phrase for the mental element of murder, has undergone a miraculous transformation over six centuries of jurisprudential development. ${ }^{33}$ Intentional killing is treated as the base because it is consistent with modern fundamental principles of criminal law. A subjective definition of murder in Canada is contained in s. 212(a)(i) of the Criminal Code which provides that culpable homicide is murder when a person causes the death of a human being under circumstances where he means to do so. The linchpin mens rea term is "means" which can be equated with intention, desire, conscious purpose,

29. See Lang v. Lang [1955] A.C. 402 (P.C.). As to whether the mental element differs where constructive desertion is alleged, see C. Davies, Family Law in Canada (1984) 409.

30. See also R.M. Perkins, "Rationale of Mens Rea" (1939) 52 Harv. L. Rev. 905 at 913-15.

31. Although a convoluted chain of causation might be found to connect a remote act by the accused with a death, to form the basis of a homicide conviction, and while one might characterize this as a constructive form of liability, that construction applies to all definitions of homicide and would be an unhelpful modifier in distinguishing among these forms. See also N. Morris, "The Felon's Responsibility for the Lethal Acts of Others" (1956) $105 U$. Of Pa. L. Rev. 50 at 59.

32. See generally J.M. Kaye, "The Early History of Murder and Manslaughter" (1967) 83 L.Q.R. 365 at 569; Law Reform Commission of Canada, Homicide: Working Paper No. 33 at 5 et seq. (1984); J.W.C. Turner Kenny's Outlines of Criminal Law (19th ed. 1966) 130-98; Sayre, supra n. 3 at 980 et seq.

33. See F. W. Maitland, The Early History of Malice Afterthought, in Collected Papers 324 at 328; J.F. Stephen, 3 History of the Criminal Law of England ch. 26 (1883); L. Radzinowics, 1 A History of English Criminal Law and its Administration from 1750 (1948); Sayre, supra n. 3 at 980 et seq. 
or a knowledge that death is certain; these are words and phrases often used to describe the mental element in crime. Under s. 212(a)(ii), murder consists of a killing by one who "means to cause bodily harm that he knows is likely to cause ... death, and is reckless whether death ensues or not". There appear to be no dissenters from the view that recklessness in this context is subjectively defined.

Traces of a constructive approach can be found in s. 212(b), which contains a rare statutory expression of the doctrine of transferred intent (or malice). It provides that where an accused intentionally or recklessly attempts to kill $\mathrm{A}$, but accidentally or mistakenly kills $\mathrm{B}$, this is murder even though there was no intention to kill the ultimate victim. Though this elastic definition of mens rea has been criticized, ${ }^{34}$ the stretching has continued, for it has now been held that a planned and deliberate attempt to kill $A$, resulting in the death of $B$, is first degree murder because the element of premeditation is transferable to an unintended victim..$^{35}$

Section 212(c) provides that murder occurs where a person, for an unlawful object, does anything that he knows or ought to know is likely to cause death (and does so), even if death or bodily harm was not desired. This provision can be traced back at least to Stephen's Digest ${ }^{36}$ and the Draft Code of 1878, ${ }^{37}$ and was contained in the Canadian Criminal Code in $1892 .{ }^{38}$ There is some suggestion that such a rule existed in Canada prior to its adoption in that Code ${ }^{39}$ but any claims to a common law ancestry must be viewed with circumspection.

Section $212(\mathrm{c})$ is designed to treat as a murderer one who sets out to achieve some criminal end - blowing up the Rainbow Warrior, to use a topical example - and in the course of that pursuit causes a death. ${ }^{40}$ This bears a strong resemblance to s. 213 , to be considered next, which characterizes as murder a death caused while committing or attempting to commit one of a list of serious offences. However, while the list in s. 213 is finite, its counterpart term in s. 212(c), the "unlawful object", is opentextured and is as difficult to define exhaustively as the phrase "unlawful act" which appears elsewhere in the Code. ${ }^{41}$ Recently, the Supreme Court of Canada has limited the potentially wide orbit of this provision by requiring that the unlawful object be an indictable offence requiring mens rea. ${ }^{42}$

Other decisions have attempted to prevent s. 212(c) from overflowing its natural banks. The failure to distinguish adequately between the unlawful object requirement and the acts done in furtherance of that object can result in an objective definition of murder which would virtually outflank the subjective definitions in s. 212(a). To illustrate, assume A resolves to

34. See especially Ashworth, supra n. 14; cf. Williams, supra n. 13 at 87.

35. Droste v. The Queen [1984] I S.C.R. 208.

36. J.F. Stephen, Digest of Criminal Law (1878) 225.

37. English Draft Code, s. 174(d).

38. S.C. 1892 , c. 29 , s. 227 (d).

39. See Crankshaw's Criminal Code (2nd ed. 1902) 236.

40. See Martin's Criminal Code (1955) 384-385.

41. See s. 205(5)(a).

42. R. v. Vasil [1981] I S.C.R. 469 at 490. 
assault B. This is an indictable offence involving mens rea and therefore qualifies as an unlawful object; and committing the assault is obviously an act done in furtherance of the initial plan. If there is mens rea sufficient to satisfy these subjective requirements of s. 212(a), then that is murder. Even if not, the acts may amount to murder if, by virtue of s. 212(c), the accused ought to have known that his assault was likely to cause death. Virtually every subjective murder charge would have s. 212(c) as a back-up. With these concerns in mind, the Ontario Court of Appeal in $R$. v. Tennant and Naccarato concluded that s. 212(c) cannot be utilized when death is caused by an assault unless the assault was committed in order to achieve some ulterior unlawful object. ${ }^{43}$ Somewhat surprisingly, the ruling on the facts in Tennant seems to ignore this statement of principle, however, the propriety of those general limitations has been confirmed in later decisions. ${ }^{44}$

In another respect the case law has put a gloss on s. 212(c). In Vasil, the Supreme Court considered the effect of drunkenness vis à vis the objective mens rea definition in that section. Lamer J., in an abstruse judgment, appears to state that the foresight of the reasonable man is to be calculated by reference to the actual knowledge of the accused, even if that knowledge is clouded by intoxication. ${ }^{45}$ If so, it allows a wide berth for the consideration of individual factors in applying an objective test: intoxication is not normally taken into account when applying a reasonable man standard in the criminal law. ${ }^{46}$

Section 213, which contains the broadest constructive murder definition in Canadian law provides, in part, that:

Culpable homicide is murder where a person causes the death of a human being while committing or attempting to commit high treason or treason ... sabotage, piratical acts, hijacking an aircraft ... escape or rescue from prison or lawful custody . . . assaulting a peace officer . . . sexual assault ... . with a weapon, threats to a third party or causing bodily harm . . . aggravated sexual assault ... kidnapping and forcible confinement ... robbery ... breaking and entering ... arson, whether or not the person means to cause death to any human being and whether or not he knows that death is likely to be caused to any human being if,

(a) he means to cause bodily harm for the purpose of

(i) facilitating the commission of the offence, or

(ii) facilitating his flight after committing or attempting to commit the of fence, and the death ensues from the bodily harm;

(d) he uses a weapon or has it upon his person

(i) during or at the time he commits or attempts to commit the offence, or

(ii) during or at the time of his flight after committing or attempting to commit the offence,

and the death ensues as a consequence.

43. (1975) 7 O.R. (2d) 687 (C.A.).

44. See R. v. Baker (1975) 28 C.C.C. (2d) 489 (Ont. C.A.); R. v. Desmoulin (1976) 30 C.C.C. (2d) 517 (Ont. C.A.); R. v. De Wolfe (1976) 31 C.C.C. (2d) 23 (Ont. C.A.). See also R. v. Vasil, supra note 42.

45. Supra $\mathrm{n} .42$ at 500.

46. "[T]he 'reasonable drunken man' would be an unworkable concept. The reasonable man is as sober as the proverbial judge": G. Williams, Textbook of Criminal Law (2nd. 1983) 95. See also R. v. Reilly (1984) 15 C.C.C. (3d) 1 at 8 (S.C.C.), where Ritchie J., in dealing with the reasonable man standard in self-defence, stated that "A reasonable man is a man in full possession if his faculties. In contrast, a drunken man is one whose ability to reason and to perceive are diminished by the alcohol he has consumed". See also R. v. Hill, supra n. 12. 
This is the modern Canadian version of the ancient, but not always revered, felony murder rule. The core of this statutory provision can be traced back through the first Criminal Code to the English Draft Code of 1879 , but the rule itself, which the section purports partially to codify (and otherwise to modify), was known as early as the time of Bracton. It has been suggested that these early origins are by no means certain and that the rule developed on a foundation premised on a misunderstanding of early authorities, coupled with a failure to take into account other significant decisions which had undermined the acceptability of the felony murder rule. ${ }^{47}$ In any event, when Parliament codified the criminal law in this polity, the English felony murder rule was apparently well entrenched, even though its precise ambit continued in a state of flux. At the heart of every expression of the rule is the notion that death caused in the commission of a felony would be murder, regardless of any intention to kill. Apart from this, there was little consensus as to the precise contours of the doctrine, and indeed not until the early twentieth century could it be said with any confidence that the rule applied only if death was caused by a violent act committed in the commission of a felony of violence..$^{48}$

Early Canadian law followed closely these English developments. And just as the common law rule developed over time, being framed narrowly by some judges and chroniclers and more expansively by others, the Canadian statutory expression of the rule has not remained static since its incorporation into the first Criminal Code in $1892 .{ }^{49}$ The most important of the incremental changes was the introduction of the present s. 213(d) in 1947 , which creates a category of felony murder where a weapon is used or carried and this results in death..$^{50}$

The Canadian provision contains elements not recognized at common law: only a listed offence can form the underlying felony and these must be accompanied by specific acts. Of prime concern here is the mens rea component, which it can be seen, might be very minimal in a given case. A would-be mugger who grabs a handbag from a middle-aged woman and throws her to the ground may be liable for murder under this section if she dies from a resulting concussion. The mens rea in this example consists of the intention to commit robbery and cause bodily harm. Notice that this goes beyond negligence; felony murder lies no matter how unforeseeable is the death of the victim. Liability for felony murder is stricter than under $\mathbf{s}$. 212(c), which requires some actual or imputed foresight of the consequences. ${ }^{\text {s1 }}$

What purposes are served by ss. 212(c) and 213? Most of the learning relates to felony murder, but the prevalent theories about the doctrine have

47. D. Lanham, "Felon Murder - Ancient and Modern" (1983) 7 Crim. L.J. 90 at 91 and passim.

48. D.P.P. v. Beard [1920] A.C. 479 (H.L.). See generally R. Moreland, The Law of Homicide (1952) 42-79.

49. S.C. 1892, c. 29.

50. See generally J. Willis, "Comment" (1951) 29 Can. Bar Rev. 432. See also J. Sedgwick, "The New Criminal Code: Comments and Criticisms" (1955) 33 Can. Bar Rev. 63 at 71.

51. See also J.G. Clark, "The Modern Felony-Murder Doctrine" (1939-40) 28 Kentucky L.J. 215 at 216. 
obvious implications for s. 212(c). A variety of reasons have been propounded and these may be conveniently sorted into three camps.

The first, which may initially appear somewhat tautological, is that treating the causing of death as murder is an appropriate expression of societal contempt for the criminal act. This is a proportionality rationale and it is underscored by several further considerations. The felony murder rule, it is said, reaffirms the sanctity of human life, manifests appropriate degrees of official disdain for the life threatening conduct and, in consequence, provides for severe penalties to reflect these attitudes. ${ }^{52}$ Consistent with this is the notion that a conviction for murder is fit and just because the accused is by no means free from the taint of fault. He has intentionally embarked on a criminal plan and must suffer the consequences - he is the author of his own misfortune. This was the sole basis upon which Holmes felt the doctrine could be defended: the degree of danger attending the commission of every felony is so high that those who engage in this activity will be liable for the homicides that result. ${ }^{33}$

The desire to put felony murder in a suitable place relative to the punishment for other crimes seems to form a recurrent theme throughout the history of the doctrine. In the early development of the common law, punishment for most felonies (including murder) was death, so that felony murder was in accord with the punishment regime then extant. ${ }^{.4}$ On one view, that offered by Hall, the special treatment of killings in the course of a felony may have initially emerged as a means of constricting the murder category: $:^{3 s}$

\footnotetext{
When early law distinguished voluntary harm-doing from misadventure, it remained for a long period content if the former were involved in any manner that could be related to the actual harm. The rule was that a person who intentionally caused any injury should be responsible for any resultant harm, however unforseeable or accidental that might be. The felony-murder, misdemeanor-manslaughter rules rose to check the range of this rationalization of penal liability as regards criminal homicide; and the ancient formulas, mala in se - mala prohibita, provided ready pegs on which to rest these important limitations. It became established that the defendant must have intended to commit a harm that was legally proscribed and that his liability for the homicide would to some substantial extent be determined by reference to the gravity of the harm he intended to commit.
}

According to more conventional explanations, as sharper distinctions between murder and manslaughter emerged, there was some validity to the assertion that punishing only the felony, or charging the accused with manslaughter, was an inadequate expression of societal condemnation. This was due to the development of the 'benefit of clergy' commencing in the early middle ages. That term originally referred to an exemption from normal penal liability granted to priests and those in lower ecclesiastical orders. These people were tried not in the royal or seigneurial courts, but in accordance with the spiritual law in the ecclesiastical courts where they

52. See D. Crump \& S.W. Crump "In Defense of the Felony Murder Doctrine" (1985) 8 Harv. J. of L. \& Pub. Policy 361-69.

53. O.W. Holmes, supra $\mathrm{n} .8$ at 57-59. See also R. v. Jarmain [1946] 1 K.B. 74; P. Weiler, "The Supreme Court of Canada and the Doctrine of Mens Rea (1971) 49 Can. Bar. Rev. 280 at 336; P. Burns \& R.S. Reid, "From Felony Murder to Accomplice Felony Attempted Murder: the Rake's Progress Compleat?" (1977) 55 Can. Bar. Rev. 75 at 80-83.

54. See W. Blackstone, 4 Commentaries on the Laws of England 204.

55. J. Hall, General Principles of Criminal Law (2nd ed. 1960) 129. 
were liable to suffer penance, to be defrocked or transported, rather than being subject to the harsh temporal punishments, which included blinding, castration and death. The complexion and availability of the benefit of clergy was altered and extended over time and by the 16th century it applied not just to bona fide priests and deacons, but to everyone who could read. In time, it was established by statute that manslaughter was a clergyable offence, but murder was not. ${ }^{56}$ And whereas the punishment for both could be death, those who could avail themselves of the benefit of clergy (before its abolition in 1827) ${ }^{57}$ would normally be liable to only one year's imprisonment and the branding of a mark on the brawn of the thumb. By placing killing in the course of the commission of a felony to the category of murder, the irrational and arbitrary indulgence to the literate criminal was avoided.

These particular concerns are devoid of contemporary significance, but their place has been taken by others. Some may posit that punishing the accused for both the felony and manslaughter would be an insufficient statement of condemnation. Indeed, it may not always be possible to convict an accused of manslaughter and the underlying offence, because that may be precluded by the rule against multiple convictions. ${ }^{58}$ Moreover, Crump et al.$^{s 9}$ have marshalled empirical evidence which suggests that the public considers certain forms of felony-murder to be as "serious" intentional killings. In sum, the doctrine operates in its fullest sense as a rule of treatment, regulating the tariff of punishment at what has been perceived by some as an appropriate level.

Secondly, it is axiomatic that the doctrine is supposed to serve a general deterrent function. The primary purpose of the law of homicide is the preservation of human life, and the criminal law pursues this goal by the threat and actual infliction of unpleasant treatment by which it is expected that actual offenders will be intimidated and potential ones deterred. By providing that where a death occurs in the course of the commission of serious crimes, the perpetrator shall be guilty of murder, it is expected either that the felony will not occur at all, or that it will be perpetrated in such a way as to avoid the risk of danger of life. ${ }^{61}$

The third justification for felony murder is based on pragmatic concerns for forensic or administrative efficiency. Under this heading, the felony murder doctrine can be characterized as a crude rule of evidence whereby the intention to kill was presumed by the commission of the felony. Since a "felony could be resisted to the point of killing the felon, the law presumed that a felon had the intent to kill if necessary to protect his life", ${ }^{62}$ or as

56. See Kaye, supra n. 32 at 572.

57. An Act for Further Improving the Administration of Criminal Cases in England (Criminal Law Act, 1827), $7 \& 8 \mathrm{Geo} .4$, c. 28, ss. 6, 7. As to the nature of the benefit of clergy generally, see E.J. White, Legal Antiquities (1913) 223 et. seq.

58. See e.g. R. v. Prince (1986) 54 C.R. (3d) 97 (S.C.C.).

59. Supra n. 52 at 363-65.

60. Id. at 364. See also G.D. Woods, "The Sanctity of Murder" (1983) 57 A.L.J. 161 at 165.

61. P. Weiler, supra n. 53 at 336.

62. P.F. Karpel \& T.B. Wilson, "Imputing Act and Intent in Felony Murder Cases: An Elaborate Fiction" (1966) 40 Conn. B.J. 107 at 108. See also W.H. Hitchler, "The Killer and His Victim in Felony-Murder Cases" (1948-49) 53 Dick. L. Rev. 3 at 5. 
Lambard observed: ${ }^{63}$ "the law presupposeth that he carrieth that malicious mind with him that he will achieve his purpose though it be with the death of him against whom it is directed". This is comparable to the suggestion that the constructive element of s. 212(c) was designed as an evidential aid in proving actual intent: according to Hooper's analysis, this explains why Stephen was content with s. 212(c) in the Draft Code, while at the same time he fervently rejected the traditional felony murder rule. ${ }^{64}$

The creation of such evidentiary shortcuts does not comport with present-day approaches to evidence and proof of guilt. But, placed in new dress, the rationale of forensic efficiency has been considered as still viable because the rule minimizes the danger of perjured testimony and promotes the efficient use of the limited criminal justice resources. The felony murder rule is thought to have "beneficial allocative consequences because it clearly defines the offence, simplifies the task of the judge and jury, and thereby promotes the efficient administration of justice". .5

\section{B. CRIMINAL COMPLICITY}

As with other areas of Canadian criminal law, the rules relating to parties to an offence are an unhappy collection of Code provisions, glued together by some common law and common sense. The primary statutory sources are ss. 21 and 22 of the Criminal Code, which set out the modes of party participation. Nowhere does the present Code state that parties are guilty of the offences in which they participate ${ }^{66}$ but the case law has filled this gap, and while the absence of an express statutory nexus between a secondary perpetrator and the crime committed seems inconsistent with the principle of legality, the existence of such a link has never been judicially doubted. ${ }^{67}$

To some extent all party liability attaching to those who do not commit an offence is ex hypothesi constructive. A person actually commits an offence when he performs the defined actus reus. Those who only aid or abet, etc., may be liable though their acts do not even remotely resemble the defined actus reus; the same is true of any form of vicarious criminal liability.

Section 21(1) renders liable the perpetrator of a crime and those who aid and abet. Liability for the secondary participants is based on subjective mens rea. Section 21(1)(b) provides that one who aids must do so for the "purpose of aiding" implying an intention to aid. Section 21(1)(c), which deals with abetting, but contains no reference to the requisite mental element, has likewise been treated as containing a requirement of a

63. Lambard, 2 Eirenarcha, at 239 quoted in J.W.C. Turner, "Malice Implied and Constructive" [1958] Crim. L. Rev. 15 at 16. "This plainly treats the question as one of evidence by which subjective intention can be established": J.W.C. Turner, id.

64. A Hooper, "Some Anomalies and Developments in the Law of Homicide" (1967-68) 3 U.B.C.L. Rev. 55 at 61-64.

65. Crump et al. supra n. 52 at 375.

66. Compare the wording of the Code prior to the 1954 amendments. The old provision stated that "everyone is a party to and guilty of an of fence who ". . . commits, aids or abets an of fence": see Criminal Code, R.S.C. 1927, c. 36, s. 69.

67. See R. v. Harder [1956] S.C.R. 489; R. v. Hall (1984) 3 O.A.C. 296. See also Martin's Criminal Code, supra n. 40 at 64. 
subjective intention to abet. ${ }^{68}$ The only major deviation may be the notion that an aider or abettor who undertakes to assist another having no certain idea as to what crime is to be committed, will nevertheless be liable if the criminal act ultimately completed falls within the range of those offences contemplated by aider or abettor. Such a proposition, adopted in an English case $^{69}$ involving an accomplice to terrorist activities, appears appropriate to Canadian law. ${ }^{70}$

By contrast, in s. 21(2) the potential for constructive party liability is pronounced. It provides that where there is an agreement to carry out an unlawful purpose, all parties to the agreement are criminally responsible, not only for pursuing to completion the unlawful purpose, but for any offence committed which they knew, or ought to have known, would be a probable consequence of carrying out that purpose.

The theoretical construct of this provision is not complex. The starting point is the existence of a common unlawful purpose. Assuming this exists, liability for derivative offences may be imposed if two further preconditions are met. There must be a causal connection between the plan and the derivative offence - the latter must have been committed in furtherance of the common plan." Additionally, the potential scope of offences is limited by the actual or imputed foresight of the accomplice. Caught by this provision are those offences which the accomplice realized or should have realized would flow from the original plan. This precondition serves double-duty, acting also as the definition of the requisite mens rea of the accomplice. Thus, the mens rea of the party may be either subjective (foresaw) or objective (ought to have foreseen). A similar approach is taken to one who counsels or procures the commission of an offence. Such a person is a party even if the counselled offence is completed in a way different from that proposed, and he is liable for any offence which he ought to have known was likely to be committed in consequence of the counselling or procuring. ${ }^{72}$

Much has been written about the reasons supporting or explaining the felony murder rule, but there is a paucity of discussion, ex cathedra or otherwise, as to the functions of the constructive element of s. 21(2). The basis for the Canadian version of the doctrine of common unlawful purpose must mirror to some degree those advanced for constructive murder. ${ }^{73}$ The law may be seen as discouraging criminal combinations by expanding the potential liability through the vehicle of s. 21(2). It provides a statutory warning that punishment may be extended to cover liability for

68. R. v. Curran (1977) 38 C.C.C. (2d) 151 at 156-57 (Alta. C.A.) leave to appeal to the Supreme Court of Canada refused; $R$. v. Barr (1976) 23 C.C.C. (2d) 116 (Ont. C.A.).

69. D.P.P. (N.I.) v. Maxwell [1978] 3 All ER 1140 (H.L.).

70. See R. v. Dunlop \& Sylvester [1979] 2 S.C.R. 881; see also R. v. Hartford \& Frigon (1979) 51 C.C.C. (2d) 462 at 468 (B.C.C.A.); V.G. Rose, Parties to an Offence (1982) 11.

71. R. v. Bannister (1936) 66 C.C.C. 352 (N.B.C.A.); Narcisse v. The Queen (1981) 22 C.R. (3d) 179 (B.C.C.A.).

72. Criminal Code, R.S.C. 1970, c. C-34, s. 22(2), as am. by S.C. 1985, c. 19, s. 7.

73. See generally V.G. Rose, supra n. 70 at 65 : "The common unlawful purpose provisions of the Criminal law seem to have been developed under the common law a doctrine of constructive murder - a sort of "constructive aiding and abetting" in murder cases. 
crimes beyond those actually intended. ${ }^{74}$ This deterrent element may create an incentive for confederates to restrain each other in the execution of their common design, since each may bear the responsibility for the dangerous zeal of the others. ${ }^{75}$ The same type of approach is sometimes said to explain why the "directing mind and will" concept is used in the context of corporate criminal liability; by penalizing the corporation for the illegal acts of its directing mind, shareholders and other interested parties are encouraged to scrutinize those who are employed in important positions in the corporate structure. ${ }^{76}$ Deterring criminal combinations likewise resembles one basis for the law of conspiracy.

The doctrine of common unlawful purpose may be no more than an attempt to punish accomplices for carrying out the express and implied terms of their unlawful agreement. An express agreement to shoot X may carry with it an implied term to commit a further discrete crime, for example, a term to possess a restricted weapon. Through the use of s. 21(2) the court can create a catalogue of offences which can be viewed as a necessary element of their plan had the matter been considered. The common law approach to the doctrines comports well with this explanation. There, the primary question is whether the derivative offence fell within the 'scope' of the original plan, which suggests an endeavour to read between the lines of that plan. The Canadian provision can be characterized in a similar way: the terms are defined partially by what the accused impliedly intended, or by reference to what a reasonable man would have seen as implicit." The actual perpetrator can then be regarded as acting as an agent for the others in carrying out the terms of the accord. ${ }^{78}$

\section{MULTIPLE FICTIONS IN CANADIAN CRIMINAL LAW: THE CASE OF TRINNEER AND ITS FAITHFUL FOLLOWERS}

Constructive liability, or more particularly the felony murder rule in its various forms, has been the target of trenchant attack for centuries. Surely few laws have provoked such a plethora of vitriolic comments. Stephen's description of the doctrine as "cruel and monstrous" 79 is well known; it has also been characterized as a "medieval and repulsive doctrine," ${ }^{\circ 0}$ and in

74. See also M. Sornarajah, "Common Intention and Murder Under the Criminal Codes" (1981) 59 Can. Bar Rev. 727 at 737.

75. Id.

76. See R. v. McNamara (No. I) (1981) 56 C.C.C. (2d) 193 at 315 (Ont. C.A.), affd. sub nom. Canada Dredge \& Dock v. The Queen (1985) 19 C.C.C. (3d) 1 (S.C.C.). See also L.H. Leigh, "The Criminal Liability of Corporations and Other Groups" (1977) 9 Ottawa L. Rev. 246.

77. See P. Gillies, The Law of Criminal Complicity (1980) 90-91.

78. See also M.A. Rabie, "The Doctrine of Common Purpose in Criminal Law" (1971) 88 South African L.J. 227 at 228-29.

79. Stephen, supra n. 36 at 57, referring to Foster's formulation (see M. Foster, Crown Law 258 (2nd ed. 1791)).

80. W.H. Hitchler, supra n. 62 at 6 . 
simple terms, a "disgrace" ${ }^{81}$ It should not be surprising therefore that some have called for its abolition ${ }^{82}$ including, recently, the Law Reform Commission of Canada. ${ }^{83}$ Following the recommendations of the Royal Commission on Capital Punishment, the rule was abolished in England in 1957.84

The arguments promoting abandonment are predictable. On point of principle, the rule has been stigmatized as overly harsh; out of step with the basic criminal law fault concept; too rigid in its application of an objective standard; and insensitive to the presumption of innocence and the rights of the accused. The proportionality of punishment has been doubted, as has the super-added deterrent effect. ${ }^{85}$ These responses will be addressed below as they relate to multiple fictions, where defects in the justifications for felony murder are more evident. ${ }^{86}$

A logical point of departure for a consideration of multiple legal fictions is the well known case of $R$. v. Trinneer, ${ }^{87}$ where the accused was convicted of (what was then called) non-capital murder, by virtue of the combined effect of ss. 21(2) and 213(a) of the Code. The principal was one Isaac Frank. On the morning of the killing, Frank had purchased a hunting knife (in the presence of Trinneer), with a view of committing robbery, should an opportunity to do so avail itself. Later that day, the two accused hitchhiked a ride in the car of one Rose Violett and while in that car (on the highway somewhere near Vancouver), Frank pulled out the knife and threatened Mrs. Violett. Frank then assumed the driving, took the car thirty-six miles

81. Per McCardie J. in R. v. Bell, quoted in Note, "Constructive Murder" (1929) 67 L.J. 450. For further critical reviews of the felony murder rule in its various forms., see Note "Recent Extensions of Felony-Murder Rule", (1955-56) 31 Ind. L.J. 534; D.A. Stroud, Mens Rea (1914) 171; W.M. Beasley \& J.P. Coleman, "Constitutional Limitations Upon the Use of Criminal Presumptions and the Felony-Murder Rule" (1975) 46 Miss. L.J. 1021; M.E. Pirsig, "Proposed Revision of the Minnesota Criminal Code" (1962-63) 47 Minn. L. Rev. 417; J.A. Johnson, Note, (1970-71) 9 Duquesne L. Rev. 122; Note, "Felony Murder as a First Degree Offence: An Anachronism Retained" (1956-57) 66 Yale L.J. 427; J.J. Hippard, "The Unconstitutionality of Criminal Liability Without Fault: An Argument for a Constitutional Doctrine of Mens Rea" (1972-73) 10 Houston L. Rev. 1039; J.H. Seibold, "The FelonyMurder Rule: In Search of a Viable Doctrine" (1977-78) 23 Cath. Law 133; cf. Crump et al., supra n. 52; F.C. Moesal, "A Survey of Felony-Murder" (1954-55) 28 Temple L.Q. 453; Note, (1974) U. of III. L.R. 685; G.S. Meiner, "The Felony-Murder Doctrine Under the Oregon Criminal Code of 1971" (1971-72) 51 Oregon L. Rev. 603. It would appear that one well-known (albeit fictitious) criminal lawyer regards the existence of constructive mens rea as rather inconsequential. Consider the following exchange in J. Mortimer Rumpole for the Defence (Penguin ed. 1982) at 53:

“"Rumpole of the Old Bailey", eh? How very amusing; said the law tutor Grice. 'What do you think of academic lawyers down at the Old Bailey?'

'Well to tell you the truth; I had to admit, 'we hardly think of them at all:

'But you'll have read my paper on "The Concept of Constructive Intent and Mens Rea in Murder and Manslaughter" in the Harvard Law Review?' Humphrey Grice looked puzzled and not a little hurt.

'Oh rather?' I lied to him. 'Your average East End jury finds it absolutely riveting'

82. See Lanham, supra n. 47 at 101; Turner, supra n. 3 at 261; P.A. MacKinnon, "Two Views of Murder" (1985) 63 Can. Bar Rev. 130 at 140; Law Reform Commissioner (Victoria), Murder: Mental Element and Punishment (Working Paper No. 8, 1984) at 10-13.

83. Supra n. 32. See also n. 155, infra.

84. Homicide Act, 5 Eliz 2, c. 11.

85. See Law Reform Commission of Canada, supra n. 32.

86. See also text accompanying n. 153, infra.

87. R. v. Trinneer [1970] S.C.R. 638. 
outside of Vancouver to an isolated location and after escorting the victim "some distance from the car", ${ }^{88}$ he inflicted mortal stab wounds. During the stabbing Trinneer had remained in the car.

On these facts it seems clear that Frank was guilty of murder, either because he had committed an intentional killing, or by virtue of the felony murder rule. Trinneer's culpability for murder posed more difficult juridical problems. It is by no means certain that he had aided or abetted the stabbing, or that he knew that this was within Frank's contemplation. Likewise, there was nothing to suggest that he counselled or procured the attack. Trinneer's guilt, if any, rested on the operation of s. 21(2) and the issue in the case centred on the nature of the foresight required under that provision.

Three main interpretive options appear to exist. ${ }^{89}$ Section 21 (2) speaks of actual or imputed foresight of a derivative offence, and it may mean therefore that foresight of murder must exist. This is at one and the same time both totally accurate, yet miserably vague, begging the further question as to what is meant by the word 'murder' in this context. The second option refines this problem somewhat. Felony murder might loosely be defined as an unintentional killing in the course of a felony. Under this option foresight must relate to such a killing, for that can accurately be described as the offence. Or, thirdly, the imputed foresight may be tied to the state of mind of the actual perpetrator. Using this approach, Trinneer's foresight of death need not be shown, since it is not necessary that the perpetrator desired or foresaw such a result. This treats the word 'offence' in s. 21(2) as meaning that portion of an offence for which the principal must possess mens rea. That seems an interpretation less faithful to the text of the Code than the others. Nevertheless, the trial judge selected this latter option, directing the jury to determine whether the accomplice, Trinneer: $:^{90}$
knew or should have known that in the course of carrying out this robbery the other accused Frank would probably cause injury to this lady of the nature that was applied to her; and that injury was caused to her either for the purpose of facilitating the commission of the robbery or facilitating the flight after committing it.

A majority of the British Columbia Court of Appeal ${ }^{\text {I1 }}$ regarded this direction as being in error, preferring the first option, as expressed in earlier case law..$^{92}$ However, a unanimous Supreme Court restored the conviction at trial, endorsing the jury charge. Cartwright C.J., for the Court, acknowledged that earlier Supreme Court decisions had referred to foresight of murder, but added that this could include any of the forms of murder in ss. 212 or 213 . Consequently, ${ }^{93}$

If [Trinneer] ought to have known it was probable that bodily harm would be inflicted on the deceased to facilitate the carrying out of the robbery, then it was unnecessary for the Crown to establish that he ought to have foreseen that her death was likely to result. The

88. Id. at 640-41.

89. For a fourth alternative, see Stuart infra $\mathrm{n} .151$.

90. Supra n. 8 at 642-3.

91. (1969) 10 C.R.N.S. 1 (B.C.C.A.).

92. See R. v. Guay [1957] O.R. 120 (C.A.); Cathro v. The Queen [1956] S.C.R. 101; Chow Bew v. The Queen [1956] S.C.R. 124; R. v. Eng. Git Lee (1956) 23 C.R. 345 (B.C.S.C.).

93. Supra n. 87 at 644-45; see also id. at 645-46. 
offence contemplated by s. 21(2) (that is, murder as defined [s. 213] (a) and/or (d)) was committed when Frank inflicted the bodily harm on the deceased for the purpose of facilitating the robbery or flight. Its character was determined when her death ensued.

The flaw in this reasoning has already been identified. It is the offence which must be foreseen and at the irreducible core of murder is the causing of death in a culpable manner. ${ }^{94}$ In fact, this is the only common denominator in the Canadian murder regime. To require only foresight of bodily harm is to concentrate solely on the means and not the result which dilutes the foresight requirement considerably.

These concerns aside, convicting Trinneer of murder on this basis is not consistent with fundamental doctrine and the idea of fair labelling. In a proper case (perhaps even in Trinneer), the facts may be such that the accomplice has no actual foresight as to the elements of any derivative offence. Whereas in relation to Frank it was necessary to demonstrate that he meant to cause bodily harm, in convicting Trinneer it was only essential to prove that he ought to have foreseen the intentional infliction of bodily harm. He may have had no thoughts about the probability, even though a reasonable man would have been alert to this danger. When this is taken together with the notion that the accomplice need not have committed any part of the actus reus of murder, it becomes still more evident that convicting Trinneer for murder (and sentencing him to life imprisonment) is an overreaction. This is not an instance where the law can reflect varying degrees of culpability in sentencing, save for the ability to postpone the time for parole eligibility. ${ }^{95}$

These criticisms can be explained by reference to the jargon of multiple fictions: s. 21(2) contains a legal fiction treating subjective and objective mens rea alike. Plus, the felony murder rule eliminates the need to show an intention to kill or foresee death. When added together, the result is that the accomplice can be convicted of murder though he neither thought about attacking, nor wished to attack, the victim. The only subjective mens rea is the intention to commit a robbery. The accomplice, labelled a murderer, is in no better position than a cold-blooded killer.

The bootstrapping logic of Trinneer has been caustically attacked, ${ }^{, \%}$ but, relentlessly, it has been applied and explained in a number of cases. ${ }^{97}$ The focus in Trinneer was on para. (a) of s. 213, but its reasoning carries at least as far as the other paragraphs of that section. ${ }^{98}$ Subsequent decisions, such

94. Id. at 644-645.

95. See also J.C. Smith, Book Review: D. Stuart, Canadian Crininal Law (1983) 21 U.W.O.L. Rev. 198 at 201.

96. See e.g. P. Weiler, supra n. 53 at 363. See also Burns \& Reid, supra n. 53.

97. See R. v. Govedarop (1974) 3 O.R. (2d) 23 (C.A.); R. v. King (1974) 18 C.C.C. (2d) 193 (Ont. C.A.); R. v. Joyce (1978) 42 C.C.C. (2d) 141 (B.C.C.A.), leave to appeal to the Supreme Court of Canada refused; $R$. v. Augustus, infra n. 106; R. v. Laviolette (1983) 42 Nfld. \& P.E.I.R. 91 (P.E.I.C.A.); R. v. Puffer, infra n. 105; R. v. Caouette, infra n. 99; R. v. Gamble, infra n. 112; R. v. Munro, infra n. 108; R. v. Moore, infra n. 110; R. v. Riezebos, infra n. 103; R. v. Hayes (1985) 14 W.C.B. 153 (N.S.C.A.); R. v. Wong (1978) 41 C.C.C. (2d) 196 (B.C.C.A.); R. v. Riendeau [1983] C.S.P. 1127 ; R. v. Roud (1981) 58 C.C.C. (2d) 226 (Ont. C.A.), leave to appeal to the Supreme Court of Canada refused.

98. But see Mackinnon, "The Path of Felony Murder" (1979) 11 Ottawa L. Rev. 509 at 512-13, where the author persuasively argues that Trinneer applies only to s. 213(a). 
as $R$. v. Caouette, ${ }^{9 \%}$ have confirmed this view. There the accused had helped plan a burglary. A co-conspirator, one Daigle, was to enter a house while Caouette waited in a car outside. The burglary was bungled when Daigle entered the wrong dwelling and the occupant of that home was mortally wounded while attempting to defend himself. The issue of Caouette's responsibility reached the Supreme Court, where Trinneer was applied. After referring to the passage quoted above, ${ }^{100}$ Fauteux C.J. stated: ${ }^{101}$

The jury ... . had to decide whether ... Caouette knew or ought to have known not only that Daigle would have with him and would use if needed the weapon owned jointly by them, while or at the time he would be committing or attempting to commit the theft, or during or at the time of his flight after committing or attempting to commit such theft, but also that Caouette knew or ought to have known that if the need arose Daigle would cause bodily harm by whatever means he could in order to facilitate the commission of this theft or his flight.

This passage is potentially misleading. The Chief Justice referred to the offence of theft, which is not listed in s. 213, instead of the appropriate felony, namely burglary. A more critical mistake relates to the apparent requirement that Caouette must have foreseen (or ought to have foreseen) both the use of the weapon and the infliction of bodily harm. A plain reading of s. 213 indicates that either causing bodily harm (under para. 213(a)), or the use of a weapon (under para. 213(d)) will suffice for felony murder if death of the victim ensues as a consequence. ${ }^{102}$

In $R$. v. Riezebos, ${ }^{103}$ the Ontario Court of Appeal reviewed both Trinneer and Caouette, and in the process framed what has become a model jury charge for accomplice felony murder situations. The case involved a death occurring during the course of a taxicab robbery. Lacourciere, J.A. set out the appropriate legal approach in relation to the facts of the instant case in these terms: ${ }^{104}$

To establish against the [accused] the essential elements of the offence of murder as defined in s. 213 through s. $21(2)$, involve[s] proof beyond a reasonable doubt of the following:

1. That the accused and Gibson formed an intention in common to carry out the robbery of a taxi driver and assist each other therein;

2. That it was a probable consequence of the prosecution of the robbery that Gibson would intentionally cause bodily harm to the taxi driver to facilitate the robbery or the subsequent flight;

3. That it was known or ought to have been known by the accused that such consequence was probable;

4. In the alternative it was known or ought to have been known to the accused that Gibson had upon his person a weapon and would use it if needed (per Fauteux, C.J.C., in R. v. Caouette . . .).

5. That Timothy Alward's death ensued from such bodily harm or as a consequence of such possession or use of such weapon.

This formulation is succinct, and it clearly indicates that liability under $s$. 213(a) is an alternative to s. 213(d).

99. [1973] S.C.R. 859.

100. See text accompanying n. 93 , supra.

101. Supra n. 99 at 866-67. (Emphasis added).

102. For further comments on this case see Burns \& Reid, supra n. 53 at 91-93.

103. (1975) 26 C.C.C. (2d) 1 (Ont. C.A.).

104. Id. at 20-21. 
In the jury charge in Trinneer, the trial judge spoke of foresight of injury "of the nature that was applied" 10 to the victim. Subsequent cases have demanded less precision in the foresight required in a charge under $\mathbf{s}$. 213(a). So, the Manitoba Court of Appeal has decided that it was immaterial whether the actual bodily harm differs from that actually foreseen.$^{106}$ Likewise, the Alberta Court of Appeal rejected the argument that the bodily harm must be of the same kind as the accomplice agreed upon for the constructive murder provisions to apply. While recognizing that the Supreme Court had endorsed the jury charge in Trinneer, it was noted that this point had not been at issue before the court. ${ }^{107}$

A comparable position obtains in relation to s. 213(d). In R. v. Munro ${ }^{108}$ two accused were charged with the shooting death of a police officer which occurred in the course of a bank robbery. One crucial issue in that case related to the nature of foresight which need be possessed by the accomplice where the murder charge rests on para. (d). It was held that there is no requirement of precise knowledge (actual or imputed) that the gun is loaded, nor that the gun will be discharged or displayed. To satisfy this component of liability, all that was required was that the accomplice knew or ought to have known that the perpetrator had a gun and would use it in some way, if need be. This issue was rather moot on the facts of Munro since both accused were armed, and had apparently agreed to brandish the guns to enforce compliance with their demands during the bank holdup; this can constitute the "use" 109 of weapons as that word is employed in s. 213(d).

The more recent Ontario case of $R$. v. Moore, ${ }^{110}$ involved yet another robbery and murder of a taxicab driver. The evidence indicated that Moore had instigated the robbery, had participated in its planning by inter alia providing essential information as to how to locate the victim and dispose of the cab, and had procured an individual to assist in the crime. The Court of Appeal was prepared to conclude that such participation could support a finding that Moore had formed an intention in common with two others. The difficult legal point was whether Moore's participation in the crime, which occurred before its commission, could also show that he had agreed to assist the others in the commission of the crime, as required under $\mathrm{s}$. 21(2). Unlike prior accomplice felony murder cases, the accused Moore was not present at the scene and had apparently stated during the planning stage that "nobody was supposed to get hurt"." Still, he was convicted of second degree murder. The jury was charged in accordance with Reizebos and although re-charging was necessary on the inter-relationship between ss. 21(2) and 213(d), no appeal was taken by the accused concerning this aspect of his trial.

105. Supra n. 87.

106. R. v. Puffer [1976] 6 W.W.R. 239 (Man. C.A.).

107. R. v. Augustus [1977] 6 W.W.R. 36 (Alta. C.A.).

108. (1983) 36 C.R. (3d) 193 (Ont. C.A.), leave to appeal to the Supreme Court of Canada refused.

109. See Rowe v. The King [1951] S.C.R. 713, cited with approval in Munro, supra n. 108.

110. (1984) 15 C.C.C. (3d) 541 (Ont. C.A.), leave to appeal to the Supreme Court of Canada refused.

111. Id. at 548 . 


\section{FURTHER EXAMPLES OF MULTIPLE FICTIONS}

The cases considered above have served to refine further the basic ruling in Trinneer. The reasoning there is certainly capable of analogous extensions, some of which have already been identified and applied by the courts. An example can be found in the Alberta case of $R$. v. Gamble. ${ }^{112}$ There, a plain clothes police detective was killed by Nichols in the aftermath of an armed robbery of a credit union. The co-accused, Janice Gamble, did not enter the credit union. However, there was evidence that she was performing a surveillance function in the front of the building. This suggests that she had agreed to aid and abet the robbery and the jury was so directed. Her liability for murder, however, appeared to rest on the combined effect of ss. 21(2) and 213. In describing this basis of liability both the trial judge and the Court of Appeal purported to adopt the Riezebos model; the trial judge thought that the common unlawful purpose was the agreement to resist arrest after the robbery, whereas the Court of Appeal considered that it was the robbery itself.

In the end, Gamble, the accomplice, was convicted of first degree murder (as was the perpetrator), because the deceased victim was a peace officer acting in the course of his duties. The Court of Appeal assumed that knowledge by the perpetrator that the victim was a police officer must be proven, ${ }^{113}$ and presumably the jury was satisfied beyond a reasonable doubt that this knowledge existed. But it does not follow that the accomplice should be convicted of first degree murder. Even employing Trinneer, it must be shown, at least, that the accomplice ought to have foreseen that the victim would probably be a peace officer. This flows from Trinneer, because the requisite mens rea of the accomplice in that case was defined by reference to the mens rea of the perpetrator. Unfortunately, there is no treatment of this issue in the unanimous decision of the Court of Appeal.

The Gamble judgment contains obiter dicta which appear to carry the Trinneer reasoning into new areas. Sinclair J.A., in a concluding passage, referred to the potential liability for murder based on the combination of the "aiding" provision of the Code. He observed that there was "powerful evidence which, if accepted by the jury, could have established [the accomplice's] guilt through the combination of s. 21(1)(b) and 213"..14 That evidence suggested merely that the accomplice had aided the robbery and Mr. Justice Sinclair's statement could be construed to mean that if an individual commits acts for the purpose of aiding a felony, and death results, then the aider will be deemed to have aided a felony murder. This would be an enormous extension of Trinneer; the need to show even the foreseeability of bodily harm would be obviated under this rule.

Without alluding to this dicta, two Ontario cases have firmly rejected such an approach. In $R$. v. Howard "1s the accused had been charged with a felony murder which occurred during the course of a garden-variety taxi

112. (1978) 40 C.C.C. (2d) 415 (Alta. C.A.).

113. Id. at 421.

114. Id. at 429.

115. (1983) 3 C.C.C. (3d) 399 (Ont. C.A.). 
cab robbery. Following an imperfect charge to the jury based on the Riezebos boilerplate direction, the judge instructed the jury as to the possibility that the accomplice had aided the felony murder by aiding the robbery. The Court of Appeal held that guilt for felony murder by means of aiding or abetting requires more than merely aiding and abetting the underlying offence. This was endorsed by the same court in Munro. ${ }^{116}$

Other potential analogous applications of Trinneer are to date unsupported by judicial authority. Undoubtedly, it can be applied when an accomplice has counselled or procured an offence within the meaning of $s$. 22(2) of the Code. Consider also the combined effect of ss. 21(2) and 212(c). Assume that a perpetrator and an accomplice agree to place a small bomb in the factory of a corporate competitor as an act of sabotage. Neither suspects that there is anyone on the site but in fact there is a security guard in the building who is killed when the bomb explodes. By virtue of $s$. $21(2)$ he is liable for all offences which he foresaw or ought to have foreseen would flow from the agreement to plant the bomb. Following Trinneer, it can be argued that he is liable if he ought to have foreseen murder as defined in any of its forms, including ex hypothesi s. 212(c). As in Trinneer, his mens rea is defined by reference to that of the perpetrator and under $\mathrm{s}$. 212(c) this mens rea may be partially constructive. Consequently, if the two constructive elements (in ss. 21(2) and 212(c)) are added together this appears: the accomplice is liable if he foresaw or ought to have foreseen that the principal would pursue an unlawful purpose and foresaw or ought to have foreseen that a death might occur. This is a multiple fiction flowing from Trinneer, if applied literally. One can combine s. 21(2) with manslaughter 'by unlawful act' to produce a similarly confusing, complicated formula for accomplice liability. All that need be shown is that the accomplice, in forming the intention in common, ought to have foreseen that the accused would commit an unlawful act.

Trinneer has had a major impact on the law of criminal attempts, principally through the Supreme Court of Canada decision in Lajoie v. The Queen. ${ }^{17}$ In that case (which has now been overruled), ${ }^{118}$ the Court drew upon the "somewhat analogous" concerning the range of the possible mentes reae for the attempted murder. The question arose because of the ostensible conflict of two Code provisions, which had fostered a divergence of jural opinion. ${ }^{120}$ Section 24 contains the general prohibition against attempted crime, providing in part that "[e]very one who, having an intent to commit an offence, does ... anything for the purpose of carrying out his intention is guilty of an attempt .... Additionally, s. 222, which is nestled within the homicide provisions, deals specifically with attempted murder, stating that "[e]veryone who attempts by any means to commit murder is guilty of an indictable of fence. .. In a nutshell, a unanimous Supreme Court held in Lajoie that the specific attempted murder provision (s. 222) affected the meaning given to

116. Supra n. 108.

117. [1974] S.C.R. 399.

118. See Part V infra.

119. Supra $\mathrm{n} .117$ at 406.

120. These cases are reviewed in Lajoie, supra n. 117 at $402-404$. 
the general section (s. 24). This meant that it was not necessary to prove a direct intention to kill so long as the accused possessed one of the mental states required for murder itself, including recklessness. In so holding, Martland J., speaking for the Court, contrasted s. 222 (then s. 210) with the comparable section as it appeared before the omnibus Code amendments in 1954. The former section expressly required an "intent to commit murder" where the charge was attempt. Those words no longer appear in the Code, suggesting the absence of a requirement of subjective intention. Moreover, s. 222 presently speaks of attempting murder "by any means". This was taken to refer to the various definitions of murder in the Code, each defining a different mens rea. Consequently, if an accused satisfies any of the mens rea requirements in ss. 212 or 213 , and the actus reus of an attempt is present, a finding of attempted murder should result. Trinneer was employed to fortify this position and after providing the factual and legal underpinning for that case, Martland J. concluded: ${ }^{121}$

In relation to the present case the important point is that, in applying s. 21(2) to the offence of murder, this Court held, in the Trinneer case, that "the commission of the of fence" meant commission in any of the ways contemplated by the Criminal Code and not merely its commission in the form of an intentional killing. Similarly, in my opinion, when s. 24(1) refers to "an intent to commit an offence", in relation to murder it means an intention to commit that of fence in any of the ways provided for in the Criminal Code, whether under s. 201 (now s. 212) or under s. 202 (now s. 213).

Lajoie does not strictly raise a problem of multiple fictions. There was employed at best just one fictional notion: the extended mens rea definition. It is the inchoate nature of the crime of attempt which produces the multiple fiction effect. Note too that the result of Lajoie violates the policy of fair labelling. Under Lajoie an accused could have been charged with attempted murder via recklessness even though he did not try to kill. Applying Lajoie to s. 213, a charge of attempted murder might arise where an accused wields a gun and commits or attempts to commit one of the offences listed in s. 213. As long as one can conclude that the actus reus of attempted murder exists - that is, acts beyond mere preparation - then there will be nothing to prevent a conviction for attempted murder. Presumably, hoodlums firing a warning shot into the ceiling during a liquor store robbery have committed attempted murder. To plead that there was no sufficient act of attempt because death was factually impossible will not likely succeed.

Burns and Reid ${ }^{122}$ identified a further means whereby Lajoie might create a problem of multiple fictions (though they employed different terminology). Assume in the liquor store robbery scenario that waiting outside was an accomplice who had agreed to help commit the robbery. The Trinneer rule provides that where murder is charged it need only be shown that the accomplice ought to have foreseen that a weapon might be used. Under Lajoie, no greater mens rea would be required, so the man sitting outside waiting for a robbery to occur could be convicted of attempted murder, even though neither he nor the principal contemplated such a result and even though no real attempt on the life of another occurs. ${ }^{123}$

121. Id. at 407-408.

122. Supra n. 53 at 87-103 passim.

123. See R. v. Barber, unreported, February 28 th, 1973, Vancouver 1010/71 (B.C.C.A.), referred to in Burns \& Reid, supra n. 53 at 102. 
The narrowest framing of the ratio in Lajoie would centre on whether recklessness (in s. 212(a)(ii)) could serve as an alternative to intention as a form of mens rea for attempted murder ${ }^{124}$ During a taxi-cab robbery the accused had fired a pistol at the driver in a way that suggested an intention to kill, or recklessness as to that result. The decision is couched in broad terms, suggesting that any of the available mens rea definitions in ss. 212 or 213 will suffice. Thus, in $R$. v. Berry ${ }^{125}$ a conviction for attempted murder was founded on s. 212(c). However, in R. v. Stevens ${ }^{126}$ the New Brunswick Court of Appeal refused to extend Lajoie in this way, holding that the causing of death was a prerequisite to the applicability of s. 212(c). Similar resistance has been met to the suggestion that Lajoie applies to s. 213. In Sarginson ${ }^{127}$ Rae J. regarded such an application as wrong in law and apt to lead to absurd results, such as those described above. ${ }^{128} \mathrm{He}$ quite reluctantly applied para. 213(a) to attempted murder because he felt bound by two appellate decisions on point. ${ }^{129}$ But he refused to use s. 213(d), taking the view, despite Lajoie, that there was no binding authority requiring him to do so. Other decisions have likewise treated the broad proposition in Lajoie touching on s. 213 as obiter dictum. ${ }^{130} \mathrm{It}$ is difficult to see how one can so conveniently escape the effect of the decision, when the reasoning takes an all-or-nothing approach to the homicide sections. Treating the statements in Lajoie as dicta suffers too from a certain jurisprudential frailty, since the Supreme Court of Canada has asserted that even its obiter statements are binding on lower courts. ${ }^{131}$

\section{A RETREAT FROM MULTIPLE FICTIONS: $A N C I O$ V. THE QUEEN}

In 1973, Burns and Reid lamented that "because both Trinneer and Lajoie are unanimous decisions of the Supreme Court of Canada the only hope of advancing the state of the law lies with Parliament". ${ }^{132}$ Now it is apparent that these commentators failed to appreciate the alacrity with which the Supreme Court could perform a volte-face. In Ancio v. The Queen, ${ }^{133}$ the Supreme Court, by a seven to one margin, expressly overruled its earlier decision in Lajoie.

124. On this basis, Lajoie was applied in $R$. v. Comeau (1973) 14 C.C.C. (2d) 472 (N.S.C.A.); $R$. v. Marrone (1980) 40 N.S.R. (2d) 348 (C.A.); R. v. Campeau (1983) 42 A.R. 81 (C.A.). See also R. v. Campbell (1977) 38 C.C.C. (2d) 6 (Ont. C.A.).

125. (1977) 37 C.C.C. (2d) 559 (B.C.S.C.).

126. (1982) 66 C.C.C. (2d) 401 (N.B.C.A.).

127. (1976) 31 C.C.C. (2d) 492 (B.C.S.C.).

128. See text accompanying n. 122, supra.

129. R. v. Barber, supra n. 123; R. v. Beeman (1975), unreported 305, 326, 328.

130. R. v. Hannah (1982) 3 C.C.C. (3d) 116 (N.B.C.A.); R. v. Ancio, infra n. 133. Lajoie seems to have been ignored in $R$. v. Horvath (1981) 6 W.C.B. 134 (Ont. Cty. Ct.), decided prior to the Court of Appeal judgment in Ancio.

131. See R. v. Sellars [1980] 1 S.C.R. S27. See also R. v. Riendeau, supra n. 97 at 1138, where Lanctot J. of the Quebec Superior Court applied Lajoie to s. 213(d).

132. P. Burns \& R.S. Reid, "Comment" R. v. Lajoie (1973) 8 U.B.C.L. Rev. 364 at 374. See also $R$. v. Sarginson, supra n. 127 at 495 (per Rae J.); “One might be permitted, however, out of a deep concern that the law shall appear to be just, to express the hope that the whole matter of attempted murder and its relationship to s. 213 may be reconsidered at an early date."

133. [1984] 1 S.C.R. 225. 
Ancio was charged with the attempted murder of the companion of his estranged wife. In November, 1980, the spouses separated and the wife commenced cohabitation with one Michael Kurrelli. Approximately one month later the accused telephoned his wife, whom he knew to be living with Kurrelli. The accused had asked the wife to go over to their son's apartment because he had been threatening to commit suicide. For several reasons the wife refused. Mr. Ancio, who had been drinking and was apparently in violent temper, then armed himself with three shotguns ('borrowed' without permission from a friend) and attended at Kurrelli's home, breaking into it. ${ }^{134}$ Both Mrs. Ancio and Kurelli were in the upstairs portion of the home when the accused entered and while Mrs. Ancio phoned the police, Kurrelli picked up a wooden chair, upon which was draped a jacket, and proceeded to the upstairs hallway. Seeing the accused at the bottom of the stairs pointing a loaded gun Kurrelli threw the chair at him. The accused later testified that when the chair hit him he stumbled backwards and the gun discharged once. That shot went through the jacket on the chair and into a wall, missing Kurrelli (who had moved behind that wall) by three feet. Because Kurrelli was behind the wall when the shotgun discharged, he did not know whether it had been intentionally fired or had gone off when the chair struck Ancio. Forensic testing indicated that the gun was not prone to accidental discharge. In any event, after this shooting the two men commenced fighting and at one stage Ancio had struck the victim on the head with an unidentified object, drawing blood..$^{135}$

On these facts the accused was convicted of attempted murder by Provincial Judge N.J. Anjo, who applied Lajoie and s. 213. The trial judge concluded that the felony was breaking and entering with the intention of committing an indictable offence, which in this case was tersely described as "forcible confinement or worse". ${ }^{136}$ It was reasoned that had the shot killed Kurrelli this would, beyond debate, be felony murder and though that result did not occur, that was "nothing for which the accused should receive a reward". ${ }^{137}$

Both the Ontario Court of Appeal and the Supreme Court of Canada rejected this decision, the tenor of the reasoning of these two appellate bodies being in basic harmony with each other. MacKinnon A.C.J., on behalf of a unanimous court of Appeal, concluded that subjective intention or recklessness must be proved to found a charge of attempted murder. The policy arguments advanced in this paper underscore the reasons reached by the appellate court. One is the desirability that true crimes possess as a constituent element a subjective mens rea. This is of special importance in the law of attempts where it is said that the mens rea forms the primary or 'fundamental' element, this latter term being used by

134. The trial judge's view of the reasons prompting the visit were less complimentary to Mr. Ancio: "They say jealousy is a very strong passion, and I think that's what this crime is all about." (R. v. Ancio, unreported, March 2, 1981, at 9 (Ont. Prov. Ct.)).

135. R. v. Ancio, id. at 8; Transcript of Evidence at 43.

136. R. v. Ancio (1981) 63 C.C.C. (2d) 309 at 314 (Ont. C.A.) quoting the unreported trial judgment.

137. Id. 
the Ontario Court of Appeal in the instant case. The other is the value of fair labelling: ${ }^{138}$

While counsel for the Crown argues that the social policy of the legislation is to protect against certain types of crime "where death may ensue", it is surely not social policy to interpret legislation, if it is possible to do otherwise, to lead to what the ordinary person in the street, whom the law is intended to serve, would consider a manifestly absurd result.

The absurdities to which this passage refers, reflect a sensitivity to the multiple fiction phenomenon. The literal application of Lajoie to a charge based on felony murder could mean that the use of a weapon during a felony attracts a charge of attempted felony murder in virtually every case of armed robbery, theoretically even if there was no potential victim at the scene of the crime. These hypotheticals, advanced in the Court of Appeal judgment, may be somewhat extreme, for they neglect the actus reus requirement that there be some factual proximity as between the acts of attempt and the completed offence. ${ }^{139}$ His Lordship might have used as an illustration the attack by Ancio on Kurrelli. The trial judge did not rely on this incident, but that act could support a finding of attempted felony murder under Lajoie.

If this were a matter of first impression, the reasons advanced in the Court of Appeal could well support a conclusion that the limited mens rea of s. 213 is insufficient for attempted murder; however the Court was required to contend with the authority of Lajoie. The ratio decidendi of that case was confined to the proposition that intention or recklessness are sufficient mentes reae. Because the trial judge had made no finding of fact as to the state of mind of the accused (having taken the view that it was unnecessary for him to do so), a new trial was ordered.

The Supreme Court of Canada did not treat Lajoie with deference, choosing rather to overrule it. Ritchie J., in dissent, regarded Lajoie as indistinguishable from the present appeal and considered himself bound by that decision; his curt dissenting opinion contained no more. The majority held that attempted murder required the specific intention to kill. This is inconsistent with even the most narrowly circumscribed ratio in Lajoie and by excluding recklessness goes one step further than the Court of Appeal. A number of lower courts have now applied this ruling without ado. ${ }^{140}$

It is interesting that the composition of the Supreme Court has changed considerably since Lajoie. Only two of the justices who heard that case were active when Ancio was argued: Ritchie J., the lone dissenter, and

138. Id. at 319. See also R. Marlin, "Attempts and the Criminal Law: Three Problems" (1976) 8 Ottawa L. Rev. 517 at 527; $R$. v. Sarginson, supra n. 127 at 494.

139. The Crown seems to have been leading to this factor. The Court of Appeal summarized these arguments (supra n. 136 at 319), stating: "Her ultimate submission was that, (to eliminate the illogical consequences of a literal interpretation) before the Crown could be successful on such a charge, there must be some proven act from which death could or may result - there has to be a "possibility" of death ensuing from the act:"

140. See R. v. Baines (1985) 7 O.A.C. 67 (C.A.); R. v. Beaver (1984) 64 N.S.R. (2d) 158 (C.A.); $R$. v. Travers (1984) 14 C.C.C. (3d) 34 (N.S.C.A.); R. v. Hotte (1984) 13 W.C.B. 224 (Alta C.A.); R. v. Matz 91985) 13 W.C.B. 376 (Man. Q.B.); R. v. Palmer (1984) 13 W.C.B. 1 (Ont. Cty. Ct.); $R$. v. Braun (1984) 12 W.C.B. 281 (Alta. C.A.); R. v. Singh (1985) 14 W.C.B. 52 (Ont. C.A.). See also R. v. Chabot (1985) 7 O.A.C. 180 (C.A.). 
Laskin C.J.C., who took no part in the decision in Ancio. ${ }^{141}$ Yet one must be careful not to let this ad hominem explanation deflect attention from the reasons for rejecting Lajoie. McIntyre J., on behalf of the majority, squarely and cogently challenged the reasoning in Lajoie.

The technical argument in Lajoie focussed on the wording of (what is now) s. 222 of the Code. After an extensive review of the legislative history, it was concluded in Ancio that s. 222 does not define the offence of attempted murder, but rather establishes a separate penalty. Amendments to earlier Code formulations were regarded as cosmetic; the net result of such amendments was that the general definition and penal provision for attempts (s. 24) governs attempted murder. This provision defined an attempt, in part, as an act committed "with an intent to commit an offence". Further, it was held that the phrase "by any means" in s. 222 did not incorporate by reference the forms of murder in ss. 212 or $213: 142$

the reference to "any means" in s. 222 refers to ways in which murder could be accomplished, such as by poisoning, shooting or stabbing. The earlier version of s. 222 . . . listed the various methods by which a killing could be effected, but the illustrations were replaced in the 1953-54 revision with a general reference to murder "by any means". In any event, ss. 212 and 213 have nothing to do with the means of killing. They are concerned solely with describing the mental elements which will suffice to make a completed killing murder.

Since the result of Ancio is that the mens rea for attempted murder requires a higher form of subjective awareness than all forms of murder but one, McIntyre J. sought to explore why this should be so. His Lordship briefly contrasted the evolution of the present murder and attempt provisions. Although this excursus lacks direction and clarity, a persuasive argument emerges nevertheless. Murder, it was noted, initially required no specific intentional element and presently may be committed by an accused possessing any one variety of mental states. In contrast, the intentional element in the law of attempts has always been central, so that McIntyre J. thought it "abundantly clear that the criminal element of the offence of attempt may lie solely in the intent". ${ }^{143}$ Therefore it was not illogical that the mental element for murder should differ from that of attempted murder though, in conclusion, the Court added parenthetically that any illogical results in this area stemmed from the Code's characterization of unintentional killing as murder.

\section{CONCLUSION: FURTHER CONSTRUCTIVE CRITICISM}

By refusing to extend the impact of the constructive homicide provisions of the Code, the Supreme Court in Ancio has implicitly recognized the concept of fair labelling. At least as important is that court's willingness to reject its earlier holding, for this opens a door to the re-examination of Trinneer: Lajoie, after all, was based on an extension of the ratio of Trinneer and involved the same 'illogical' constructive murder provisions.

141. The panel in Ancio was comprised of the following: Ritchie, Dickson, Beetz, Estey, McIntyre, Chouinard, Lamer and Wilson JJ. and Laskin C.J.C. In Trinneer the bench consisted of: Abbott, Martland, Judson, Ritchie, Hall, Spence, Pigeon, Laskin JJ. and Fauteux C.J.C.

142. Supra n. 133 at 250.

143. Id. at $247-48$. 
The overruling of one of its decisions is not an unprecedented act by the Supreme Court. In 1969, Laskin J. (as he then was) observed that the Supreme Court had abandoned a rigid view of stare decisis with respect to both its own and Privy Council decisions (on appeal from Canada) adding that this step had been taken "without the blare of trumpets". ${ }^{144}$ In addition to Ancio there have been at least five occasions in which it has overruled itself ${ }^{145}$ in the last decade, so Trinneer cannot be viewed as sheltered from attack by some notion of precedential immunity.

To reject Trinneer would not require a court to outflank the clear and unequivocal intention of Parliament; Trinneer is not based on a plain reading of the Code and may be abandoned as freely as Lajoie. It may be that the draftsmen did not completely appreciate problems which can arise in the combined operation of some Criminal Code sections. For example, for some years it had been a matter of conjecture as to whether one could be guilty of an attempt to conspire. From a technical perspective, there seems nothing to prevent the combination of the attempt provision (s. 24) with the general conspiracy provision (s. 423). However, in Dungey ${ }^{146}$ it was held that the offence of attempting to conspire to commit a further offence was not known to the law. The two offences have overlapping, though not purely identical, rationalia. The main element of commonality is the use of these inchoate offences to prevent the planned substantive offence from coming to fruition. To couple these two preventive devices together could create criminal liability at a very remote state of criminal planning - a stage well before either of the inchoate offences operating individually was designed to operate. For this reason the Ontario Court of Appeal held that the dovetailing of the two sections was wrong.

The relevance of this tack to Trinneer should be patent: in two places the law establishes constructive liability for reasons which appear to overlap. Furthermore, given the difficulties of interpretation (which are far more perplexing than those confronted in Dungey), it would seem appropriate to draw upon the principle that a penal statute should be construed strictly in favour of the accused. Although this canon of construction has been something of a battered fortress in recent years, on occasion confined ${ }^{147}$ or ignored ${ }^{148}$ its validity continues to be recognized. ${ }^{149}$ The British academic J.C. Smith, has provided a reminder of the value of sensible statutory interpretation in the Canadian context. Referring specifically to Trinneer, he observed that "[w]hen the interpretation departs so widely from the ordinary meaning of the words used, the Code becomes a trap for the

144. B. Laskin, The British Tradition in Canadian Law (1969) 67.

145. K. v. Mr. \& Mrs. B. (1985) 57 N.R. 17 (S.C.C.); Hill v. The Queen [1977] 1 S.C.R. 827; Paquette v. The Queen [1977] 2 S.C.R. 189; McNamara Construction (Western) Ltd. v. The Queen [1977] 2 S.C.R. 654; Bell v. The Queen, [1979] 2 S.C.R. 212; See G. Gall, The Canadian Legal System (2nd ed. 1984) 228; see also G. Bale, "Casting Off the Mooring Rope of Binding Precedent" (1980) 58 Can. Bar Rev. 255.

146. (1980) 51 C.C.C. (2d) 86 (Ont. C.A.); cf. R. v. May (1984) 13 C.C.C. (3d) 257 (Ont. C.A.) (leave to appeal to the Supreme Court of Canada refused).

147. See R. v. Budget Car Rentals Ltd. (1981) 31 O.R. (2d) 161 (C.A.).

148. See R. v. Verrette [1978] 2 S.C.R. 838.

149. See e.g., Abbas v. The Queen (1984) is C.C.C. (3d) 513 (S.C.C.); see generally, S. Kloepfer, "The Status of Strict Construction in Canadian Criminal Law" (1983) 15 Ottawa L. Rev. 553. 
unwary, which is worse than having no Code at all:"'so A strict and logical construction of the Criminal Code would have required the Crown in Trinneer to have proven that the accused, in agreeing to the robbery, foresaw or ought to have foreseen that the infliction of bodily harm or the use of a weapon might cause an unintended death i.e. that a felony-murder might occur. ${ }^{151}$

One may ask whether the policies supporting the felony murder rule are compelling in relation to co-felons lacking subjective foresight. Under the rule, punishment is seen as fitting because the accused is said to have brought on his own misfortune; this has a hollow ring when used to describe the accomplice. ${ }^{152} \mathrm{His}$ only 'mental participation' may be to assist in pursuing a common unlawful purpose and some other person may perform the actus reus in a manner which is beyond his control. Only if he is at fault for entering into the original agreement, or for omitting or failing to curb the derivative actions of his confederate, would it follow that the accomplice is the author of his own misfortune. He is at best a subordinate co-author, making a secondary contribution. To purport to treat the two parties alike for this reason (at least for the purposes of conviction) in essence treats the accomplice more harshly, since his mental state and actual participation will be less than the principal.

The empirical studies intimating citizen support for the felony murder do not touch on the accomplice's position. The scant evidence which exists suggest that the accomplice is viewed as less morally culpable than the perpetrator. ${ }^{133}$ And after examining the manner in which the law treats other murderers, i.e. the provoked or drunken killer, the vicarious liability imposed upon the accomplice seems disproportionately high.

The forensic certainty and efficiency rationale for felony murder can be dismissed out of hand: it trivializes the trial process and seriously derogates from the presumption of innocence. And whether deterrence requires retention of objective accomplice felony murder is difficult to answer given the absence of evidence as to its efficacy. However, remembering that the choice is as between the deterrent effect of a murder conviction as opposed to one for the felony or manslaughter, some indication that a marginal increase in deterrence should exist before the outbalancing of basic principles of culpability is to be countenanced.

The so-called rule against multiple fictions may be recognized in many ways. One is by means of the ameliorative statutory interpretation discussed above. Another is through statutory reform. The Law Reform Commission of Canada's recommendation ${ }^{154}$ that the felony murder rule be abolished would solve most of the practical problems canvassed in this paper. More far-reaching would be the Commission's recent proposal to

150. Smith, supra n. 94 at 201.

151. See also Stuart's compromise solution in "Annotation: R. v. Munro (1983) 36 C.R. (3d) 193 at 197: "Surely, for liability as a party to murder under ss. 21(2) and 213(d), a requirement, following proof of the common intent, of reasonable foresight of the probability of the principal using the weapon in a life-threatening way would [be a] sensible [construction]". (Emphasis added).

152. But cf. R. v. Laviolette, supran. 97 at 109-110.

153. See H. Kalven \& H. Zeisel, The American Jury (1966) 443-45.

154. Supra n. 81. 
remove the constructive mens rea element from the doctrine of common unlawful purpose. ${ }^{135}$

Of course, the Charter ${ }^{156}$ may have an important role to play, though the present state of the authorities suggests otherwise. In $R$. v. Bezanson ${ }^{157}$ the Nova Scotia Court of Appeal upheld the validity of s. 213 in the face of a challenge based on ss. 7 and 11 (d) of the Charter. Even assuming that s. 7 protects substantive due process (a matter which has now been resolved), ${ }^{158}$ the court rejected the argument that this right had been infringed. Accepting that removing the mens rea requirement may indeed constitute an infringement, it was said that s. 213 could not be so characterized, because it contains merely a reduced form of mens rea. And as s. 213 does not reverse the burden of proof, it was held that there was no contravention of s. 11(d).

The Bezanson decision was relied upon in $R$. v. Laviolette ${ }^{159}$ where the Prince Edward Island Court of Appeal upheld the validity of the accomplice felony murder rule. In Laviolette, McDonald J. rejected the submission that s. 21(2) of the Code could affect the presumption of innocence, which the Code provision neither reverses nor negates. The same was said to be true of s. 213(d) alone and the two Code sections in conjunction with each other. ${ }^{160}$ In a separate concurring judgment, McQuaid J. considered s. 11(d) to be irrelevant to the issue, adding that the accomplice felony murder rule, which required that an independent tribunal find guilt beyond a reasonable doubt, and was the "practical embodiment" 161 of the protections contained in s. 11(d). Finally, on a subsidiary ground, pleaded initially but apparently not argued before the court, McQuaid, J. held that the sentencing regime for second degree murder was not at odds with the standards of Canadian society and therefore did not constitute cruel and unusual punishment in a manner contrary to s. 12 of the Charter.

These two decisions were decided prior to the landmark Supreme Court of Canada decision in Reference Re Motor Vehicle Act ${ }^{162}$ That decision has opened the door for a full consideration of the effect of s. 7 of the Charter on the accomplice felony murder rule, an issue not considered in the Court of Appeal decision in Laviolette. The Supreme Court of Canada is now considering that decision. In an excellent article appearing in this volume, ${ }^{163}$ the felony murder rule is tested against the crucible of the Charter;

155. Law Reform Commission of Canada, 1 Recodifying Criminal Law (Report 30) (1986) 44 (Clause 4(6)(c)). See also Law Reform Commission of Canada, Secondary Liability (Working Paper) (1985) 45.

156. Canadian Charter of Rights and Freedoms, Constitution Act, 1982 Part I.

157. (1983) 8 C.C.C. (3d) 493 (N.S.C.A.), leave to appeal to the Supreme Court of Canada refused.

158. See infra. n. 162.

159. Supra., n. 97. Leave to appeal to the Supreme Court granted.

160. Id. at 113. Campbell J. concurred.

161. Id. at 110. See also the curious comments at 109: "s. 21(2) does not concern itself with intent, or mens rea, but rather with knowledge or constructive knowledge".

162. (1986) 48 C.R. (3d) 289 (S.C.C.).

163. See I. Grant and A.W. MacKay, "Constructive Murder and the Charter: In Search of Principle" also appearing in this issue of the Alta L. Rev. 
that exercise will not be repeated here. However, without indulging in the details of Charter doctrine in relation to ss. 1 and 7, much of what has been said above may be marshalled to expose a contravention of a s. 7 right. The multiple fiction phenomena creates a definition of mens rea seriously at odds with subjective mens rea defined under general principles of criminal law. In result, fair labelling of criminal conduct is also ignored. Even assuming that the continued existence of the felony murder rule can be justified under s. 1 of the Charter, it has been argued above ${ }^{164}$ that these justifications lose force when applied to the accomplice. In consequence, such extended forms of criminal liability should no longer be tolerated.

164. See text accompanying nn. 152 to 153 , supra. 